\title{
Key determinants of dog and cat welfare: behaviour, breeding and household lifestyle
}

\author{
Q. Sonntag ${ }^{(1) *} \&$ K.L. Overall ${ }^{(2)}$ \\ (1) Department of Companion Animal Clinical Studies, Faculty of Veterinary Science, University of Pretoria, \\ Private Bag X04, Onderstepoort, 0110, South Africa \\ (2) 10 County Lane, Glen Mills, PA 19342, United States of America \\ *Corresponding author: quixi.sonntag@up.ac.za
}

\begin{abstract}
Summary
The changing role of companion animals, accompanied by changes in human lifestyle and demands, places them at risk of poor welfare. They are increasingly subjected to stressors that prevent the adequate expression of normal behaviour. Fear and anxiety often go unrecognised, leading to behavioural disorders that are accompanied by negative affective states and poor welfare. Irresponsible breeding practices result in increased incidences of inherited defects in pets, which adversely affect physical and mental aspects of welfare, either directly, through the anomaly itself, or indirectly, due to secondary effects. Increased urbanisation has resulted in smaller living spaces, higher population densities and longer working hours, all factors that affect the well-being of pets. A better understanding of animal behaviour by both pet owners and professionals, to more effectively meet the needs of dogs and cats and recognise their problems, should inform the formulation of objective welfare assessments to ensure a better quality of life for the animals. Responsible breeding practices that increase genetic diversity and select for traits that help dogs and cats fill their niche in a changing world should be based on evidence to minimise welfare risk.
\end{abstract}

\section{Keywords}

Behaviour - Canines - Cat - Companion animal - Dog - Felines - Genetics - Pet - Quality of life - Welfare.

\section{Introduction}

Companion animals have never before been as popular, played such diverse roles or acted as economic drivers to the extent that they do today. Regardless of whether the dog detects explosives or provides protection, company or social lubrication for an urban worker, or the cat functions in a disease-alert capacity or as a confidante, guidelines for remedying welfare problems are scarce. As we move from more functional relationships with animals - hunting, herding, hauling, recreation, protection, vermin control to those defined by profound changes in human lifestyle, demands and desires, we must ask how we can determine, measure and meet the welfare needs of dogs and cats.

The more demanding the roles set for dogs and cats, the more likely that these companions will be subject to stressors that prevent the adequate expression of normal behaviours (1). We currently recognise the issue of dogs and cats whose behaviours become a problem for humans; however, we must instead conduct routine, objective assessments and ask ourselves if such behaviours flag welfare risks for the dogs and cats themselves.

Ways of measuring welfare may include life expectancy, body condition, growth, disease, immunosuppression, behavioural anomalies, the prevalence of behaviours typical of particular species and breeds and the ability to make social choices (2). Behavioural and physical pathologies may be heritable, and the assessment of risk must inform modern breeding decisions (3, 4). Breeding decisions and counselling must also consider 'market conditions' as human lifestyles change. In addition, breeds that have visual and status appeal may suffer if the very traits that promote their desirability render them incompatible with the household's lifestyle (5).

Welfare issues affect veterinarians, pet owners, breeders, the burgeoning pet-care industries and the dogs and cats themselves. Here, the authors discuss emergent concerns and possible solutions. 


\section{Behaviour}

The field of behavioural therapy for companion animals is relatively new. Behavioural medicine has gained support with the establishment of special interest groups and specialist colleges such as the American College of Veterinary Behaviorists, the American Veterinary Society of Animal Behavior, the Australian and New Zealand College of Veterinary Scientists' Veterinary Behaviour Chapter, the British Veterinary Behaviour Association, and the European College of Animal Welfare and Behavioural Medicine. When an animal's environment does not fulfil its basic needs for survival and comfort, welfare is affected (6). Common welfare factors that may lead to canine and feline behavioural problems are varied (Table I) $(7,8,9,10,11,12)$. Abnormal behaviour can itself lead to welfare concerns if it causes physical injury - for example, self-mutilation or intestinal obstruction due to obsessive compulsive behaviour - and if this behaviour angers or scares the human into taking actions such as unwarranted or inescapable physical or verbal punishment or abuse.

Behavioural concerns in dogs and cats include truly abnormal behaviour, normal behaviour that is undesirable for the owner, and behaviours that may not be understood to be problematic for the dog or cat, and are instead accepted as normal. Truly abnormal behaviours include those which are out of context in terms of social or environmental stimuli, or in terms of their character, duration, frequency and/or intensity, so that they are cognitively/emotionally damaging to the dog or cat (13). Disorders like separation anxiety, noise phobia and certain types of aggression are rooted in fear and anxiety, which are negative affective states that contribute to poor welfare. If the underlying anxiety is appropriately addressed, the disorder can be resolved (13). Pet owners who are trained to recognise early signs of anxiety disorders (Box 1) $(14,15,16,17,18,19,20,21$, 22) and are encouraged to seek help early may minimise the risk that the behavioural disorder could become a major welfare issue (13).

'Undesirable behaviour' is often a function of human knowledge about normal canine and feline behaviour. If owners understand what defines 'play' in an energetic dog, what information is contained in a bark, and why cats scratch, they are often able to provide alternative substrates or circumstances for the dog or cat to express normal behaviour in a manner tolerable to their humans. Enrichment strategies can help $(20,23,24,25)$ and may be physical, social, sensory, occupational and nutritional (26).

Behaviours that may not be appreciated as problematic for the dog or cat and are accepted as normal include those exhibited during veterinary examination. In one study, fear affected $78.5 \%$ of examined dogs (27). Restraint
Table I

Welfare factors that can lead to behavioural problems

$(7,8,9,10,11,12)$

\begin{tabular}{|c|c|}
\hline $\begin{array}{l}\text { Factor / } \\
\text { Consequence }\end{array}$ & Examples \\
\hline \multirow{6}{*}{$\begin{array}{l}\text { Prolonged } \\
\text { confinement / } \\
\text { Physical and behavioural } \\
\text { debility }\end{array}$} & Commercial puppy mills/farms \\
\hline & Commercial catteries \\
\hline & Shelters with inadequate space or staff \\
\hline & Hoarders' homes \\
\hline & $\begin{array}{l}\text { Crates/runs in which dogs are confined too long } \\
\text { and/or in too small a space }\end{array}$ \\
\hline & $\begin{array}{l}\text { Any situation that denies the cat/dog the } \\
\text { minimum mental and physical exercise required } \\
\text { to not display any behaviour of concern }\end{array}$ \\
\hline \multirow{5}{*}{$\begin{array}{l}\text { Inadequate social } \\
\text { exposure during } \\
\text { sensitive periods / } \\
\text { Lack of flexibility in stress } \\
\text { response }\end{array}$} & Pet stores \\
\hline & Commercial puppy mills/farms \\
\hline & Commercial catteries \\
\hline & Hoarders' homes \\
\hline & Irresponsible breeders \\
\hline \multirow{4}{*}{$\begin{array}{l}\text { Inadequate social } \\
\text { exposure and } \\
\text { stimulation beyond } \\
\text { sensitive periods / } \\
\text { Inadequate social mastery } \\
\text { and flexibility }\end{array}$} & Breeding dogs in puppy mills/farms \\
\hline & Breeding cats in commercial catteries \\
\hline & Prolonged incarceration in inadequate shelters \\
\hline & $\begin{array}{l}\text { Neglectful/impoverished ownership } \\
\text { environments, with few opportunities for social } \\
\text { interaction, particularly with other species }\end{array}$ \\
\hline \multirow{4}{*}{$\begin{array}{l}\text { Harmful social } \\
\text { interactions / } \\
\text { Profound physical and } \\
\text { behavioural damage and } \\
\text { withdrawal }\end{array}$} & Dog fighting \\
\hline & Inappropriate/abusive training methods \\
\hline & Crowded shelters \\
\hline & Animal brokers \\
\hline \multirow{2}{*}{$\begin{array}{l}\text { Genetic selection / } \\
\text { Preference for } \\
\text { problematic behaviour or } \\
\text { lack of selection against } \\
\text { co-varying concern }\end{array}$} & $\begin{array}{l}\text { Noise reactivity/phobia as a consequence of } \\
\text { selecting for quick reactions }\end{array}$ \\
\hline & $\begin{array}{l}\text { Aggression as a consequence of selecting for } \\
\text { bold show behaviours or coat colour variants }\end{array}$ \\
\hline
\end{tabular}

methods may contribute to lasting fear and create anxiety that exacerbates pain or pruritus (28). Fear, withdrawal, the releasing of anal sacs and aggression should not be considered routine outcomes of veterinary intervention. Newer approaches designed to enhance welfare and alleviate mental distress encourage the evaluation and minimisation of stress/distress levels at all stages of veterinary evaluation (13).

Increased interest in animal behaviour has been accompanied by a profusion of advice scenarios that are not evidence-based and often compromise the animal's welfare. One example is the ongoing debate about 'dominance' and dogs. Dog owners are often told to physically 'dominate' 


\section{Box 1}

Commonly recognised non-specific signs of anxiety in dogs $(14,15,16,17,18,19)$

- Urination

- Defecation

- Anal sac expression

- Panting

- Increased respiration and heart rates

- Trembling/shaking

- Muscle rigidity (usually with tremors)

- Lip-licking

- Nose-licking

- Grimace (retraction of lips)

- Head-shaking

- Smacking or popping lips/jaws together

- Salivation/hypersalivation

- Vocalisation (excessive and/or out of context)

- Frequently repetitive sounds, including high-pitched whines, like those associated with isolation

- Yawning

- Immobility/freezing or profoundly decreased activity

- Pacing and profoundly increased activity

- Hiding or hiding attempts

- Escaping or escape attempts

- Body language of social disengagement (turning head or body away from signaller)

- Lowering of head and neck

- Inability to meet a direct gaze

- Staring at some middle distance

- Body posture lower (in fear, the body is extremely lowered and tail tucked)

- Ears lowered and possibly droopy because of changes in facial muscle tone

- Mydriasis

- Scanning

- Hyper-vigilance/hyper-alertness (may only be noticed when touched or interrupted, may hyper-react to stimuli that otherwise would not elicit this reaction)

- Shifting legs

- Lifting paw in an intention movement

- Increased closeness to preferred associates

- Decreased closeness to preferred associates

- Profound alterations in eating and drinking (acute stress is usually associated with decreases in these activities, chronic stress is often associated with increases)

- Increased grooming, possibly with self-mutilation

- Decreased grooming

- Possible appearance of ritualised or repetitive activities

- Changes in other behaviours, including increased reactivity and increased aggressiveness (may be non-specific) their dogs by neck scruffing or 'alpha rolling' them. Unfortunately, scientific data show that such actions are more likely to cause increased anxiety and aggression in the dog, and increase the risk of injury to the owner (29, 30). Attributing most behavioural problems to a perceived need of the dog to 'dominate' others has been discredited $(31,32)$ and has no place in modern companion animal partnerships $(33,34)$. Likewise, training methods that use coercion and punishment worsen canine aggression (18, 19) and create profound risks to dogs' behavioural and mental health (29).

The standard of care now includes puppy and kitten classes that expose young animals to humans and others of their species during their sensitive periods, while providing professional guidance to enable pet owners to anticipate normal, age-associated behaviours and risks. Training and behaviour modification methods are changing from being correction-based to reward-based as research reveals how animals learn best $(30,35)$. New research seeks to develop objective, quantitative assessments of normal and problematic behaviours to accurately test for and identify emerging problems $(5,36)$.

\section{Breeding}

A 2009 literature search of inherited diseases in the 50 most popular dog breeds in the United Kingdom revealed 396 inherited disorders (37). A similar study in 1963 identified only 13 abnormalities or defects in pedigree dogs (38). While we have doubtless improved in our ability to detect such conditions, there has also been a dramatic increase in the incidence of inherited disorders that are maintained through selective breeding.

The concerns for cats are fewer, and only a small percentage of cats are purebred (15\% of cats in the United States) (39).

Pedigree dogs and cats are bred to conform to published breed standards. Such standards do not evaluate or include health-promoting features $(40,41,42)$. For example, brachycephaly in dogs and cats (e.g. the English bulldog, Persian cats) results in changes in skull shape through selective breeding. Brachycephalic airway obstruction syndrome varies with skull shape and involves an elongated soft palate, stenotic nares and hypoplastic trachea, entropion, a predisposition to skinfold dermatitis around the muzzle and dystocia, necessitating birth by caesarian section (37). There are obviously significant welfare implications of these conditions.

Selective breeding in purebred animals has resulted in the loss of genetic diversity, accumulation of detrimental genes and exaggeration of anatomical features associated with physical health risks $(41,43,44)$. Irresponsible 
breeding practices include the 'popular sire syndrome', i.e. the overuse of individual breeding males leading to increased genetic homogeneity $(4,45)$, and the intentional breeding of related animals by line breeding and inbreeding $(4,44)$. The popular sire syndrome is likely to have been exacerbated by removal from the breeding population through castration (usually at the insistence of the breeder) of so-called 'pet quality' dogs who do not meet an exacting show standard but who are otherwise healthy and perfectly acceptable companion animals (43). Such practices result in, for example, Pekingese with longer noses and improved airflow not contributing to the breeding population and genetic variation. Inbreeding increases frequencies of inherited disorders, especially in those breeds with small effective population sizes $(1,42)$. Strong artificial selection for certain phenotypic traits may result in the selection of unintended traits because of the underlying genetic variance-co-variance matrices (43). For example, selection for the desired feature of curly tails in pugs is associated with an increased incidence of spina bifida (37), both of which are developmental anomalies.

Altered anatomical features may interfere with visual and olfactory communication and orthopaedic alterations like shortened limbs may affect the ability to run and play.

If selection causes an animal to be more likely to perceive aversive brain signals (for example, through a predisposition to a condition that causes pain), or results in brain changes causing an increased sensitivity to incoming noxious signals, that selection would have a negative effect on welfare (46). Two areas of welfare concern identified by the Five Freedoms - the capacity to perform normal behaviour and the need to minimise pain, injury and disease - would then be at risk (44).

Breeders need solid data and clear, logical evidence on which to base breeding decisions. Adequate data collection systems must record objective, valid information about individual animals, and these systems must be accessible and used $(4,43,44)$. Good data on the mortality/morbidity of inherited conditions permit meaningful genetic evaluations. The Generic Illness Severity Index for Dogs (GISID) is one quantitative scoring system that uses prognosis, treatment, complications and behavioural effects to produce a welfare evaluation (37). The GISID's usefulness is enhanced if prevalence estimates of inherited conditions are available (3).

Techniques used in livestock, such as estimated breeding values (EBVs), can be used in dogs and cats to evaluate the genetic effects of complex diseases; for example, hip and elbow dysplasia in dogs (45). The use of DNA testing for single gene disorders can decrease the frequency of these disorders if used in widespread screening programmes; for example, for polycystic kidney disease in cats $(39,44,45)$.
To make the best use of screening programmes, breeders, owners and veterinarians must remember that inherited conditions can be widespread within a species, but rare in specific breeds, or prevalent in certain breeds but not common within that species (42). Mixed-breed dogs and cats are also at risk of inherited defects, so it is crucial to quantify the effects of each condition in any welfare assessment.

The aim of minimising welfare risks posed by inherited conditions is to preserve genetic variation and encourage the selection of traits that result in healthy animals, predisposed to a good quality of life. Suggested strategies are listed in Table II $(5,40,41,43,44,45)$.

The most pressing need is for the systematic collection of morbidity/mortality data from all registered dogs (41). Such data must be detailed and complete to produce meaningful assessments of the prevalence of inherited conditions and their effects on welfare.

\section{Table II}

Strategies to minimise the welfare risks of inherited conditions $(5,40,41,43,44,45)$

\begin{tabular}{|c|c|}
\hline Strategy & Tactics \\
\hline Breeder education & $\begin{array}{l}\text { Encourage paradigm shift to } \\
\text { focus on health and well-being, not } \\
\text { aesthetics }\end{array}$ \\
\hline \multirow{4}{*}{$\begin{array}{l}\text { Changing/regulating breeding } \\
\text { practices }\end{array}$} & Limit number of litters/animals \\
\hline & $\begin{array}{l}\text { Restrict breeding of closely related } \\
\text { animals }\end{array}$ \\
\hline & $\begin{array}{l}\text { Restrict selection of morphological } \\
\text { extremes }\end{array}$ \\
\hline & $\begin{array}{l}\text { Open stud books to add genetic } \\
\text { variation }\end{array}$ \\
\hline \multirow[t]{3}{*}{ Public/owner education } & $\begin{array}{l}\text { Knowledge of breed use, history and } \\
\text { behaviours }\end{array}$ \\
\hline & $\begin{array}{l}\text { Teach humane and science-based } \\
\text { rearing skills }\end{array}$ \\
\hline & $\begin{array}{l}\text { Understand neurobehavioural } \\
\text { development and signalling }\end{array}$ \\
\hline \multirow[t]{4}{*}{$\begin{array}{l}\text { Create strong scientific foundations } \\
\text { for decisions }\end{array}$} & $\begin{array}{l}\text { Collaborative, interdisciplinary data } \\
\text { collection involving all stakeholders }\end{array}$ \\
\hline & $\begin{array}{l}\text { Development and validation of } \\
\text { behavioural assessments }\end{array}$ \\
\hline & $\begin{array}{l}\text { Development of genetic testing/ } \\
\text { tools for risk assessment }\end{array}$ \\
\hline & $\begin{array}{l}\text { Data-based breeding decisions and } \\
\text { policies, including those on breed } \\
\text { standards/management }\end{array}$ \\
\hline
\end{tabular}




\section{Lifestyle}

Increased urbanisation has resulted in smaller living spaces, higher population densities and longer working hours. Relocations and extensive travel are common. Pets are expected to be flexible, even while their owners may have less time to meet their needs. The number of companion animals per household may drop as living spaces become smaller (1), or more pets may be kept with less per capita space. Both extremes carry welfare implications: singly housed pets may lack sufficient social interaction (46, 47) and high-density environments may bring together incompatible individuals and provoke conflict.

Affluence allows for better veterinary care, but may correlate with less attention to social and behavioural needs (1). Dogs and cats may get less exercise, but more premium diets and treats, leading to obesity. Sub-threshold variants of such conditions as separation anxiety and obsessive-compulsive disorder may become clinically expressed as a correlation of lowered interaction levels. Lack of mental stimulation may lead to decreases in behavioural flexibility and promote reactivity or depression, a particular concern as pets' brains age.

Lifestyle effects on companion animals can be extreme. Pets acquired as fashion accessories or as status symbols may experience impaired welfare (48). Dog fighting is abusive to dogs, and mirrors problematic aggression in humans.
Urban crime renders 'protection' dogs desirable, without proper thought as to what is required to produce a dog that protects humans and their property but does not pose a risk to other humans and animals in the community (49). Economic downturns result in the neglect, abandonment and euthanasia of large numbers of dogs and cats $(50,51$, 52, 53). Zoonoses are more common in communities that lack access to competent and affordable veterinary care $(54,55)$. These scenarios are all part of the broader context needed for any welfare assessment and remediation.

\section{Conclusion}

We owe it to the animals in our care to provide them with the best quality of life possible physical health, minimising their pain and suffering and allowing them to perform natural behaviour (56). For every role that animals play with humans, a welfare assessment and mitigation plan is needed. This can only be accomplished through scientifically supported behavioural and neurobehavioural assessments, and by evaluations of how inherited diseases generate behavioural evidence of compromised welfare. Only when we do this will we have honoured the social contract made with the dogs and cats which play so many roles in human society.

\title{
Les facteurs déterminants du bien-être des chiens et des chats : comportement, élevage, et modes de vie des propriétaires
}

\author{
0. Sonntag \& K.L. Overall
}

\begin{abstract}
Résumé
L'évolution du rôle dévolu aux animaux de compagnie, parallèlement aux changements des modes de vie et des valeurs chez l'être humain ne vont pas sans comporter un certain risque pour le bien-être de ces animaux. En effet, ceux-ci sont de plus en plus soumis à des facteurs de stress qui les empêchent d'exprimer leur comportement normal. La crainte et l'anxiété sont rarement prises en compte en tant que telles, ce qui entraîne des troubles du comportement s'accompagnant d'états affectifs négatifs et de mauvaises conditions de bien-être. Des pratiques d'élevage irresponsables ont pour effet d'augmenter l'incidence des défauts héréditaires chez les animaux de compagnie, ce qui détériore les conditions physiques et mentales du bien-être, aussi bien directement du fait de I'anomalie elle-même qu'indirectement par ses effets secondaires. En raison de I'urbanisation croissante, les habitats sont de plus en plus petits, les densités de population plus élevées et les journées de travail plus longues, autant de facteurs
\end{abstract}


qui affectent le bien-être des animaux de compagnie. Si les professionnels et les propriétaires d'animaux de compagnie comprenaient mieux le comportement animal, cela les aiderait à répondre plus efficacement aux besoins des chiens et des chats et à identifier les problèmes, et permettrait également de réaliser en connaissance de cause des évaluations objectives du bien-être de ces animaux afin de leur offrir une meilleure qualité de vie. Les pratiques d'élevage responsables devraient chercher à minimiser les risques pour le bien-être animal, tout en essayant d'accroître la diversité génétique et de sélectionner des traits susceptibles d'aider les chiens et les chats à occuper la place qui leur revient dans un monde en pleine mutation.

\title{
Mots-clés
}

Animal de compagnie - Bien-être animal - Canidé - Chat - Chien - Comportement - Félin - Génétique - Petits animaux - Qualité de vie.

\section{Principales determinantes del bienestar de perros y gatos: comportamiento, reproducción y modo de vida doméstico}

\author{
0. Sonntag \& K.L. Overall
}

\begin{abstract}
Resumen
La evolución del papel de los animales de compañía, aunada a la transformación de los modos de vida y expectativas de las personas, pone en peligro el bienestar de esos animales, sujetos cada vez más a factores de estrés que les impiden la expresión adecuada de un comportamiento normal. A menudo el miedo y la ansiedad pasan desapercibidos, lo que induce trastornos de conducta que se acompañan de estados afectivos negativos y de condiciones deficientes de bienestar. Las prácticas reproductivas irresponsables inducen una creciente incidencia de defectos hereditarios en las mascotas, lo que repercute negativamente en los aspectos físicos y psíquicos del bienestar, ya sea directamente, en razón de la propia anomalía, o indirectamente, a resultas de efectos secundarios. La creciente urbanización ha traído consigo una merma del espacio vital, densidades de población más elevadas y horarios de trabajo más prolongados, factores todos ellos que afectan al bienestar de las mascotas. Es preciso que profesionales y propietarios entiendan mejor la conducta animal para poder así responder con más eficacia a las necesidades de perros y gatos, detectar sus problemas y, sobre todo, utilizar ese conocimiento como base para evaluar objetivamente el bienestar de los animales y ofrecerles mayor calidad de vida. Para reducir al mínimo los posibles riesgos de bienestar hay que aplicar prácticas reproductivas responsables, que deben reposar en criterios científicos, deparar una mayor diversidad genética y seleccionar rasgos que ayuden a los perros y gatos a ocupar el nicho que les corresponde en un mundo en plena transformación.
\end{abstract}

\section{Palabras clave}

Animal de compañía - Bienestar - Calidad de vida - Caninos - Comportamiento - Felinos - Gato - Genética - Mascota - Perro. 


\section{References}

1. McGreevy P.D. \& Bennett P.C. (2010). - Challenges and paradoxes in the companion animal niche. Anim. Welf., 19 (Suppl. 1), 11-16.

2. Broom D.M. (1991). - Animal welfare: concepts and measurement. J. Anim. Sci., 69, 4167-4175.

3. Collins L.M., Asher L., Summers J. \& McGreevy P. (2010). Getting priorities right: risk assessment and decision-making in the improvement of inherited disorders in pedigree dogs. Vet. J., 189, 147-154.

4. Leroy G. (2011). - Genetic diversity, inbreeding and breeding practices in dogs: results from pedigree analyses. Vet. J., $189,177-182$.

5. King T., Marston L.C. \& Bennett P.C. (2012). - Breeding dogs for beauty and behaviour: why scientists need to do more to develop valid and reliable behaviour assessments for dogs kept as companions. Appl. anim. Behav. Sci., 137, 1-12.

6. Hill S.P. \& Broom D.M. (2009). - Measuring zoo animal welfare: theory and practice. Zoo Biol., 28, 531-544.

7. Freedman D.G., King J.A. \& Elliot O. (1961). - Critical period in the social development of dogs. Science, 133, 1016-1017.

8. Bennett P.C. \& Rohlf V.I. (2007). - Owner-companion dog interactions: relationships between demographic variables, potentially problematic behaviours, training engagement and shared activities. Appl. anim. Behav. Sci., 102, 65-84.

9. Godbout M., Palestrini C., Beauchamp G. \& Frank D. (2007). - Puppy behavior at the veterinary clinic: a pilot study. J. vet. Behav., 2, 126-135.

10. Blackwell E.J., Twells C., Seawright A. \& Casey R.A. (2008). The relationship between training methods and the occurrence of behavior problems, as reported by owners, in a population of domestic dogs. J. vet. Behav., 3, 207-217.

11. Herron M.E., Shofer F.S. \& Reisner I.R. (2009). - Survey of the use and outcome of confrontational and non-confrontational training methods in client-owned dogs showing undesired behaviors. Appl. anim. Behav. Sci., 117, 47-54.

12. Pierantoni L., Albertini M. \& Pirrone F. (2011). - Prevalence of owner-reported behaviours in dogs separated from the litter at two different ages. Vet. Rec., 169, 468. doi:10.1136/vr.d4967.

13. Overall K.L. (2013). - Manual of clinical behavioural medicine for dogs and cats. Elsevier, St. Louis, Missouri.

14. Beerda B., Schilder M.B.H., van Hooff J.A.R.A.M. \& de Vries H.W. (1997). - Manifestations of chronic and acute stress in dogs. Appl. anim. Behav. Sci., 52, 307-319.

15. Beerda B., Schilder M.H.B., van Hooff J.A.R.A.M., de Vries H.W. \& Mol J. (1998). - Behavioural, saliva cortisol and heart rate responses to different types of stimuli in dogs. Appl. anim. Behav. Sci., 58, 365-381.
16. Overall K.L. (1997). - Clinical behavioral medicine for small animals. Mosby, St. Louis, Missouri.

17. Overall K.L., Dunham A.E. \& Frank D. (2001). - Frequency of nonspecific clinical signs in dogs with separation anxiety, storm/thunderstorm phobia, and noise phobia, alone or in combination. JAVMA, 219, 467-473.

18. Schilder M.B. \& van der Borg J.A. (2004). - Training dogs with help of the shock collar: short and long term behavioural effects. Appl. anim. Behav. Sci., 85, 319-334. doi:10.1016/j. applanim.2003.10.004.

19. Tod E., Brander D. \& Waran N. (2005). - Efficacy of dog appeasing pheromone in reducing stress and fear related behaviour in shelter dogs. Appl. anim. Behav. Sci., 93 (3), 295-308

20. Rooney N.J., Gaines S.A. \& Bradshaw J.W.S. (2007). - Behavioural and glucocorticoid responses of dogs (Canis familiaris) to kennelling: investigating mitigation of stress by prior habituation. Physiol. Behav., 92, 847-854.

21. Rooney N., Gaines S. \& Hiby E. (2009). - A practitioner's guide to working dog welfare. J. vet. Behav., 4, 127-134.

22. Mariti C., Gazzano A., Moore J.L., Baragli P., Chelli L. \& Sighieri C. (2012). - Perception of dogs' stress by their owners. J. vet. Behav., 7, 213-219.

23. Loveridge G.G. (1998). - Environmentally enriched dog housing. Appl. Anim. Behav. Sci., 59, 101-113.

24. Overall K.L. \& Dyer D. (2005). - Strategies for laboratory animals from the viewpoint of clinical veterinary behavioral medicine: emphasis on cats and dogs. ILAR J., 46, 202-216.

25. Rochlitz I. (1999). - Recommendations for the housing of cats in the home, in catteries and animal shelters, in laboratories and in veterinary surgeries. J. Feline Med. Surg., 1, 181-191.

26. Rochlitz I. (2005). - A review of the housing requirements of domestic cats (Felis silvestris catus) kept in the home. Appl. anim. Behav. Sci., 93, 97-109.

27. Döring D., Roscher A., Scheipl F, Kuchenhoff H. \& Erhard M.H. (2009). - Fear-related behaviour of dogs in veterinary practice. Vet. J., 182, 38-43.

28. Patel K.N. \& Dong X. (2010). - An itch to be scratched. Neuron, 68, 334-339.

29. Grohmann K., Dickomeit M.J., Schmidt M.J. \& Kramer M. (2013). - Severe brain damage after punitive training technique with a choke chain collar in a German shepherd dog. J. vet. Behav., 3, 180-184.

30. Hiby E.F., Rooney N.J. \& Bradshaw J.W.S. (2004). - Dog training methods: their use, effectiveness and interaction with behaviour and welfare. Anim. Welf., 13, 63-69. 
31. Bradshaw J.W.S., Blackwell E.J. \& Casey R.A. (2009). Dominance in domestic dogs: useful construct or bad habit? J. vet. Behav., 4, 135-144.

32. Mills D. \& Zulch H. (2010). - Appreciating the role of fear in fear and anxiety in aggressive behavior by dogs. Vet. Focus, $20,44-49$.

33. American Veterinary Society of Animal Behavior (AVSAB) (2008). - Dominance position statement. Available at: http:// avsabonline.org/uploads/position_statements/dominance_ statement.pdf (accessed on 15 July 2013).

34. Welfare in Dog Training (2013). - What's wrong with using 'dominance' to explain the behaviour of dogs? The Dog Welfare Campaign position statement. Available at: www.dogwelfarecampaign.org/why-not-dominance.php (accessed on 15 July 2013).

35. Fukuzawa M. \& Hayashi N. (2013). - Comparison of 3 different reinforcements of learning in dogs (Canis familiaris). J. vet. Behav., 8 (4), 221-224.

36. Christiansen S.B. \& Forkman B. (2007). - Assessment of animal welfare in a veterinary context: a call for ethologists. Appl. anim. Behav. Sci., 106, 206-220.

37. Asher A., Diesel D., Summers J.F., McGreevy P.D. \& Collins L.M. (2009). - Inherited defects in pedigree dogs. Part 1: Disorders related to breed standards. Vet. J., 182, 402-411.

38. Hodgman S.FJ. (1963). - Abnormalities and defects in pedigree dogs. 1. An investigation into the existence of abnormalities in pedigree dogs in the British Isles. J. small Anim. Pract., 4, $447-456$

39. Lyons L.A. (2012). - Genetic testing in domestic cats. Molec. cell. Probes, 26, 224-230.

40. McGreevy P.D. \& Nicholas F.W. (1999). - Some practical solutions to welfare problems in dog breeding. Anim. Welf., $8,329-341$.

41. Rooney N.J. \& Sargan D.R. (2010). - Welfare concerns associated with pedigree dog breeding in the UK. Anim. Welf., 19 (Suppl. 1), 133-140.

42. Summers J.F., Diesel G., Asher L. \& McGreevy P.D. (2010). Inherited defects in pedigree dogs. Part 2: Disorders that are not related to breed standards. Vet. J., 183, 39-45.

43. Hedhammar A.A., Malm S. \& Bonnett B. (2011). International and collaborative strategies to enhance genetic health in purebred dogs. Vet. J., 189, 189-196.

44. Rooney N.J. (2009). - The welfare of pedigree dogs: cause for concern. J. vet. Behav., 4, 180-186.
45. Lewis T.W., Woolliams J.A. \& Blott S.C. (2010). - Optimisation of breeding strategies to reduce the prevalence of inherited disease in pedigree dogs. Anim. Welf., 19 (Suppl. 1), 93-98.

46. Kirkwood J.K. (2010). - Introduction: Darwinian selection, selective breeding and the welfare of animals. Anim. Welf., 19 (Suppl. 1), 1-5.

47. Ramos D., Arena M.N., Reche-Junior A., Daniel A.G.T., Albino M.V.C., Vasconcellos A.S., Viau P. \& Oliviera C.A. (2012). - Factors affecting faecal glucocorticoid levels in domestic cats (Felis catus): a pilot study with single and large multi-cat households. Anim. Welf., 21, 285-291.

48. Buckland E.L., Whiting M.C., Abeyesinghe S.M., Asher L., Corr S. \& Wathes C.M. (2013). - A survey of stakeholders' opinions on the priority issues affecting the welfare of companion dogs in Great Britain. Anim. Welf., 22, 239-253.

49. Overall K.L. \& Love M. (2001). - Dog bites to humans: demography, epidemiology, and risk. JAVMA, 218, 1-12.

50. Patronek G.J., Glickman L.T., Beck A.M., McCabe G.P. \& Ecker C. (1996). - Risk factors for relinquishment of dogs to an animal shelter. JAVMA, 209, 572-581.

51. DiGiacomo N., Arluke A. \& Patronek G. (1998). - Surrendering pets to shelters: the relinquisher's perspective. Anthrozoös, $11,41-51$.

52. Scarlett J.M., Salman M.D., New J.C. \& Kass P.H. (1999). - Reasons for relinquishment of companion animals in US animal shelters: selected health and personal issues. Appl. anim. Behav. Sci., 2, 41-57.

53. Kwan J.Y. \& Bain M.J. (2013). - Owner attachment and problem behaviors related to relinquishment. J. appl. anim. Welf. Sci., 16, 168-183.

54. Hotez P.J. \& Wilkins P.P. (2009). - Toxocariasis: America's most common neglected infection of poverty and a helminthiasis of global importance? PLoS negl. trop. Dis., 3, 1-4.

55. Sanguinetti-Morelli D., Angelakis E., Richet H., Davoust B., Rolain J.M. \& Raoult D. (2011). - Seasonality of cat-scratch disease, France, 1999-2009. Emerg. infect. Dis., 17, 705-707.

56. Fraser D. (2009). - Assessing animal welfare: different philosophies, different scientific approaches. Zoo Biol., $28,507-518$ 